\title{
Overgang til digital aflevering og bedømmelse af skriftlige prøver ved Aarhus Universitet og Ingeniørhøjskolen i Århus
}

- Projektrapport fra Projekt

Digital Eksamen og DigEx-

Iøsningen

\section{Rasmus Blok}

Projektleder

Center for Undervisning og Læring, Aarhus Universitet.

\section{Mads Stenh $\varnothing \mathbf{j}$}

\section{Andresen}

Udviklingskoordinator

Center for Undervisning og Læring, Aarhus

Universitet.

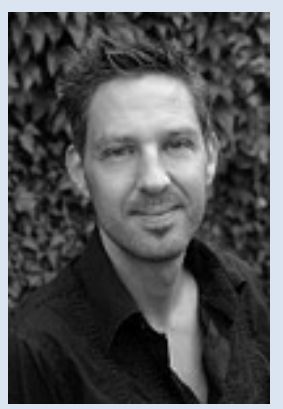




\section{Hans Sommer}

\section{Pilottest-koordinator}

Center for Undervisning og Læring, Aarhus

Universitet.

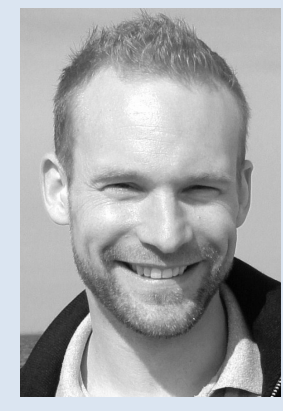

\section{Abstract}

Aarhus Universitet og Ingeniørhøjskolen i Århus vil gøre det muligt at skriftlige prøver stilles og at besvarelser afleveres, bedømmes, håndteres og arkiveres digitalt. Projekt Digital Eksamen afdækker med støtte fra ABTfonden i øjeblikket mulighederne for at afskaffe papir og gøre de skriftlige "hjemme"-prøver $100 \%$ digitale ${ }^{1}$. De foreløbige resultater er meget positive, idet studerende og studieadministrativt personale langt overvejende er begejstrede og føler sig hjulpet af digitaliseringen. Bedømmerne er også generelt positive, men hertil knytter der sig langt flere udfordringer. Nærværende artikel rapporterer midtvejs i projektforløbet om opgaven, den valgte løsning, evalueringerne og erfaringerne, samt de udfordringer digitaliseringen medfører.

\section{Sådan foregår en skriftlig prøve i dag}

Når en studerende i dag afleverer en skriftlig eksamensbesvarelse er det som hovedregel i form af computer-udprint og i tre eksemplarer - én til censor, én til eksaminator og én til universitetets arkiv (og måske en fjerde til den studerende selv). Besvarelsens 3 eksemplarer afleveres personligt på et eksamenskontor sammen med 3 håndudfyldte prøveforsider. Her bundter man dem efterfølgende med prøvens øvrige besvarelser, forsider og bilag, giver bundtet papiromslag, og forsender dem efterfølgende med både internt og ekstern (anbefalet) post rundt til prøvens eksaminatorer og censorer.

Forud for afleveringen har den studerende som regel hentet prøvens opgaveformulering (oftest på studiesekretærens kontor), udfærdiget

\footnotetext{
1 Projektet fokuserer udelukkende på de frie og bundne skriftlige hjemme-prøver, som til forskel fra de skriftlige sted-prøver, der ofte omtales i pressen i forbindelse med håndskrivning og gennemslagspapir, afvikles over længere tid udenfor universitetet. De frie og bundne skriftlige hjemme-prøver udgør ca. $90 \%$ af alle skriftlige prøver ved AU \& IHA.
} 
opgaven derhjemme på sin $\mathrm{PC}$, og endelig printet eller kopieret besvarelsen (i nærmeste kopicenter). Undervejs har en studiesekretær koordineret og administreret en blanding af tidskrævende papirgange, trukket data fra forskellige digitale studieadministrative systemer og koordineret og korresponderet med den prøveansvarlige studieleder, eksaminator og censor. Efterfølgende vil eksaminator og censor selv fragte (slæbe) stabelen af papir-besvarelser hjem eller hente den på postkontoret, med henblik på bedømmelse. Ligeledes vil en servicemedarbejder have fragtet universitets eksemplarer til loftets eller kælderens arkiv. ${ }^{2}$

Alt i alt er papirforbruget, portoomkostningerne og administrationsbyrden for afvikling af skriftlige eksamener ganske betydelig - ikke mindst når man tager mængden af de hen ved 40.000 studerende ved Ingeniørhøjskolen i Århus og Aarhus Universitet i betragtning. Der estimeres således med over 100.000 afleverede prøvebesvarelser pr. år ved AU og IHA, som i gennemsnit udgør mere end 15 sider, og som afleveres i 3 eksemplarer. Hertil skal lægges bilag, konvolutter, omslag og forsider. Det giver årligt langt over 4.500.000 udprintede papirsider, som fragtes internt og på tværs af landet.

\section{Ønsket bag digitaliseringen af de skriftlige prøver}

Ovenstående virkelighed vedrørende de skriftlige prøver har ført frem til Projekt Digital Eksamens konstaterende udgangspunkt: "Vi kan gøre det bedre!" Projekt Digital Eksamen arbejder således på at konceptualisere et digitalt workflow, der søger digitalt at sammenflette de forskellige led og data i en skriftlig eksamen, så den vanlige praksis med at udprinte opgaver og besvarelser overflødiggøres, den interne og eksterne distribution kan undgås og den megen koordination og kommunikation kan minimeres.

2 Det bør påpeges, at det ovenfor gengivne billede af en skriftlig eksamen er generelt og maler med den brede pensel. Det er sådan billedet hovedsagligt ser ud på Aarhus Universitet og Ingeniørhøjskolen i Århus, om end der her også gør sig mange andre varianter og procedurer gældende - nogle endda delvist digitaliserede. Ligeledes kan billedet se anderledes ud på andre universiteter i DK, men det er dog forfatternes erfaring, at det skitserede billede ovenfor repræsenterer majoriteten. 


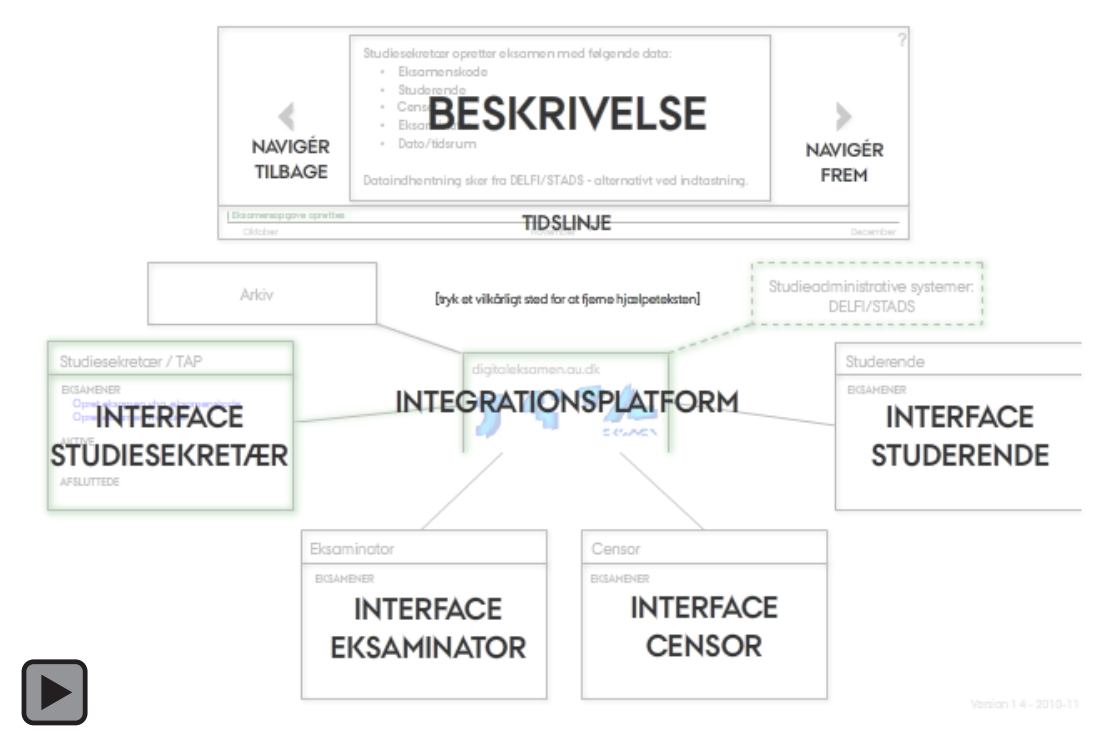

Figur 1. Animeret illustration af den digitale prøves workflow.

Dette workflow vil integrere de studieadministrative systemer med de praktiske processer, der eksisterer omkring skriftlige opgaver og derved samle afviklingen af skriftlige prøver ét og samme sted for alle involverede parter - hvad enten man er studerende, eksaminator/censor eller studiesekretær. I projektet er der således også et særligt fokus på udvikling af tilfredsstillende procedurer for censor/eksaminator i forhold til digital læsning og kommentering af besvarelser. ${ }^{3}$ Nedenfor ses et videospot, som på lidt humoristisk vis forklarer udgangspunkt og ønskede forandring:

3 Da projektet startede i det tidlige forår 2010, blev der søgt erfaringer generelt fra ind og udland mht. digitaliseringen af de skriftlige eksaminer og i særdeleshed erfaringer på digitalisering af hele det involverede workflow, herunder også digital understøttelse af bedømmelsen. Projektet fandt en række enkeltstående både danske og udenlandske forsøg, men ingen som omfattede hele universitetet/uddannelsesorganisationen og som digitaliserede hele workflowet. I mange af tilfældene var en digital aflevering koblet til et eksisterende LMS, med de udfordringer og diskrepanser der eksisterer mellem undervisningshold og eksamenstilmeldte, men ofte gik digitaliseringsprocessen ikke videre, hvorfor det efterfølgende blev printet, eller at man overlod den digitale læsning (eller udprint) til bedømmerne selv. Projekt Digital Eksamen ønskede at skabe et system som på institutionel vis understøttede hele processen, og her kender vi ikke til nogen fortilfælde. Af samme grund oplever projektet stor national og international bevågenhed. 


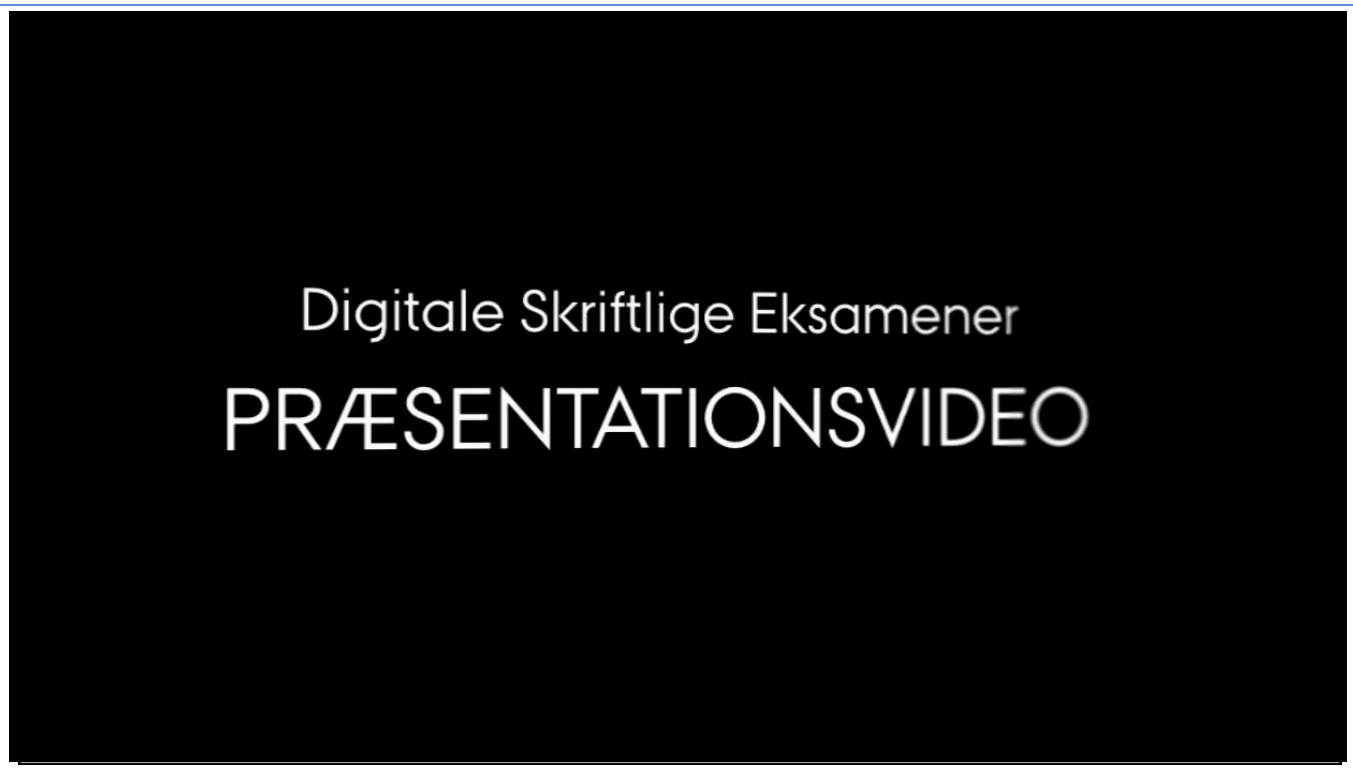

Figur 1. Videofilm om grundlaget for Projekt Digital Eksamen.

Projektets grundkoncept er derved integration; både i form af integration med eksisterende digitale administrative systemer og tjenester, men også som en integration af de allerede digitaliserede arbejdsprocesser blandt de studerende, eksaminatorer/censorer og studieadministrativt personale, som hidtil har været adskilt. Fx formulerer eksaminator oftest eksamensopgaven på sin computer, mens den udleveres som udskrevne sider. På samme vis skriver de studerende oftest prøve-besvarelserne på computer, men må aflevere den i tre udskrevne eksemplarer, ligesom studiesekretæren udarbejder eksamensprotokoller mv. på sin computer, der efterfølgende udprintes og sendes til eksaminator og censor. På den måde er projektets mål ikke at skabe endnu et system til datahåndtering, men at sammenflette eksisterende information og koble vante arbejdsgange sammen i ét digitalt bindeled, så unødige, fysiske mellemled så vidt muligt overflødiggøres.

Samtidigt er det vigtigt at koble ABT-fondens ${ }^{4}$ fordring på kvantitative forbedringer med kvalitative forbedringer for de involverede parter på $\mathrm{AU}$ og IHA. Mens ABT-fonden, der delvist finansierer projektet, har en primær fordring på arbejdsbesparende tiltag og overflødiggørelse af besværlige og tunge arbejdsgange, er AU og IHA ligeledes optaget af at skabe tiltag, der understøtter deres primære kerneprocesser. Projektet skal således på den ene side forsøge at digitalisere arbejdsprocesser ved at skære papiret væk, fjerne de manuelle processer gennem overflødiggørelse af tunge løft,

4 ABT står for Anvendt Borgernær Teknologi. Fonden er i dag omdøbt til Fonden for Velfærdsteknologi, og hører under Finansministeriet og Økonomistyrelsen, med det formål at støtte projekter der vil effektivisere den offentlige sektor gennem teknologiske løsninger. 
pakning, postomdeling mv. og skabe tættere forbindelse mellem borgeren og det offentlige gennem digitalt at forbinde de studerende og underviserne med universitetet. Alt sammen kvalitative forbedringer som ligger i ABT-fondens opdrag. På den anden side må projektet understøtte og forbedre de studerendes adgang til prøvning, lette og understøtte eksaminatorernes og censorernes bedømmelses-arbejde og endeligt styrke studieadministrationens overblik og håndtering af prøverne. Alt sammen kvalitative forbedringer, som ligger i universitets opdrag. Men til sammen også alle væsentlige parametre for at løsningen kan opnå succes for de involverede parter - både for universitetet som institution, de studerende, eksaminatorer og censorer som bedømmere og det studieadministrative personale. For man kommer jo ingen vegne med en digital løsning som fjerner papiret, hvis den samtidigt gør livet mere besværligt for de involverede brugere!

\section{DigEx - projektets løsning}

Projekt Digital Eksamen har søgt at løse den integrerede og digitaliserede afvikling af prøver gennem etablering af en nyudviklet online platform. Platformen til understøttelse af den digitale eksamen - kaldet DigEx - kan således digitalt varetage og understøtte samtlige led af en skriftlig prøve: administration, information, kommunikation, distribution og bedømmelsesarbejde. Målet med DigEx er, at denne platform er det eneste sted de prøveinvolverede har behov for at frekventere og forholde sig til i løbet af hele prøveperioden.

DigEx kobler og integrerer derved de studieadministrative systemer med de før adskilte (håndholdte som digitaliserede) arbejdsprocesser (fx eksamenstilmeldinger, tildeling af bedømmere, skrivning af eksamensbesvarelse, arkivering, korrespondance mv.) og præsenterer dem for brugerne i et samlet interface og flow.

Løsningen bag DigEx skelner mellem tre forskellige brugertyper: studiesekretæren (den på universitetet som administrerer prøven), den studerende (den eksamenstilmeldte som afleverer besvarelsen) og eksaminator/censor (dem som bedømmer besvarelserne). Afhængig af typen af bruger vil DigEx' funktionalitet og virkemåde være forskellig, således kun relevant information for den specifikke bruger præsenteres. Studerende har kun adgang til netop de prøver, som de er tilmeldt, samt arkivet over deres tidligere afleverede besvarelser. Bedømmere får kun adgang til netop de besvarelser fra en given prøve, som de er blevet tildelt bedømmelse af, samt et arkiv over tidligere bedømte besvarelser. Begge præsenteres med en grafisk fremstilling af den enkelte eksamens workflow og status. Samtidig bibeholdes et simpelt og overskueligt design, der kræver få brugerkompetencer. Dette er væsentligt eftersom platformen typisk ikke vil være et dagligdagsværktøj for de studerende og bedømmerne. Deres brug af DigEx vil oftest være koncentreret omkring eksamensterminerne 2-4 gange årligt. 


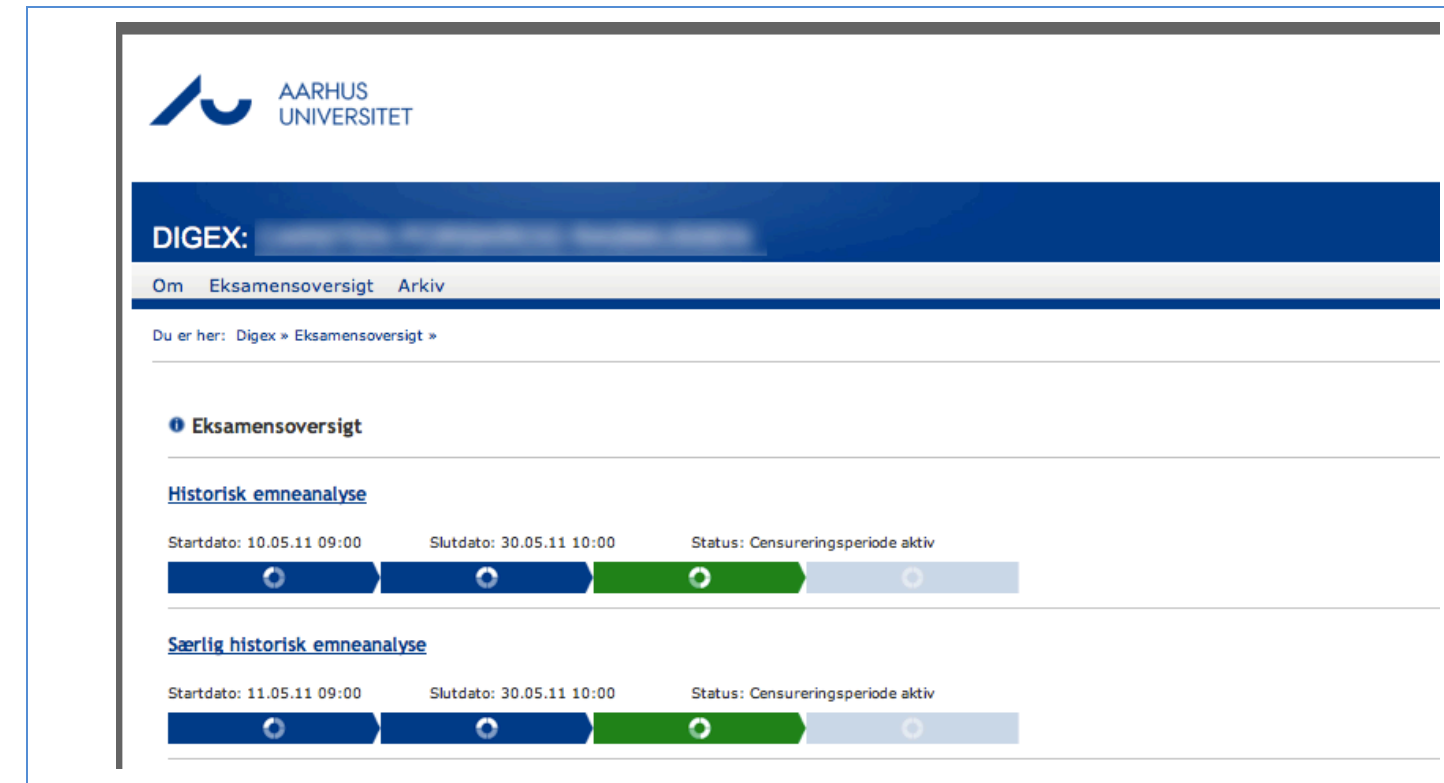

Figur 3. Ilustration af bedømmers og den studerendes oversigt over igangværende prøver.

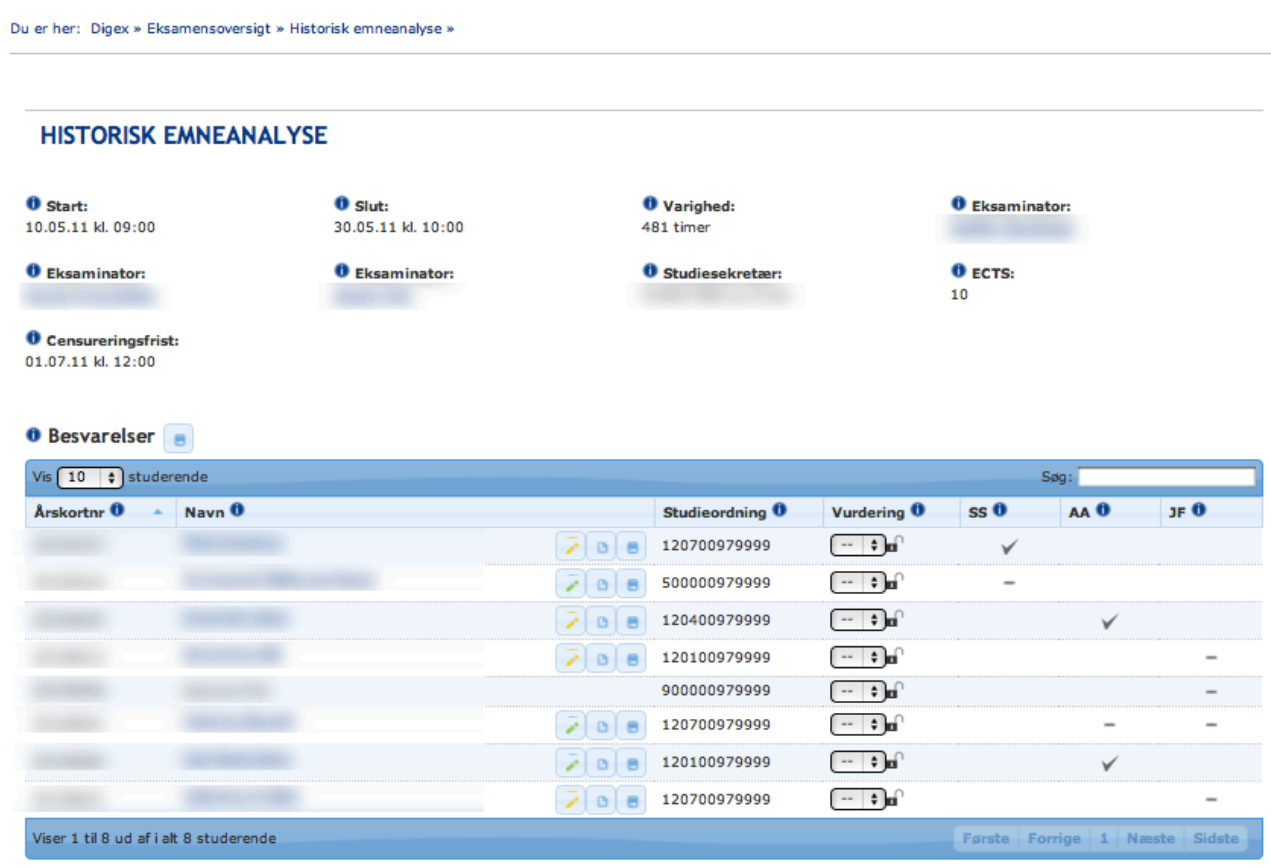

Figur 4.Illustration af bedømmers oversigt over den enkelte prøve og de studerendes besvarelser. 
Samme designstrategi er udarbejdet for studiesekretærens del af platformen, hvor kun brugerrelevant information og funktionalitet er til rådighed. Studiesekretærens arbejde på platformen adskiller sig imidlertid væsentligt fra de øvrige brugeres ved at være mere omfattende, differentieret og informationstung. Da studiesekretæren i højere grad har en kontinuerlig brug af DigEx, hvor planlægning og opsætning strækker sig ud over hele semestret, illustreres de enkelte eksaminers workflow ikke grafisk. Af samme grund vedligeholdes vedkommendes brugskompetencer også mere jævnligt, hvorfor designet er mere komplekst og mindre grafisk.

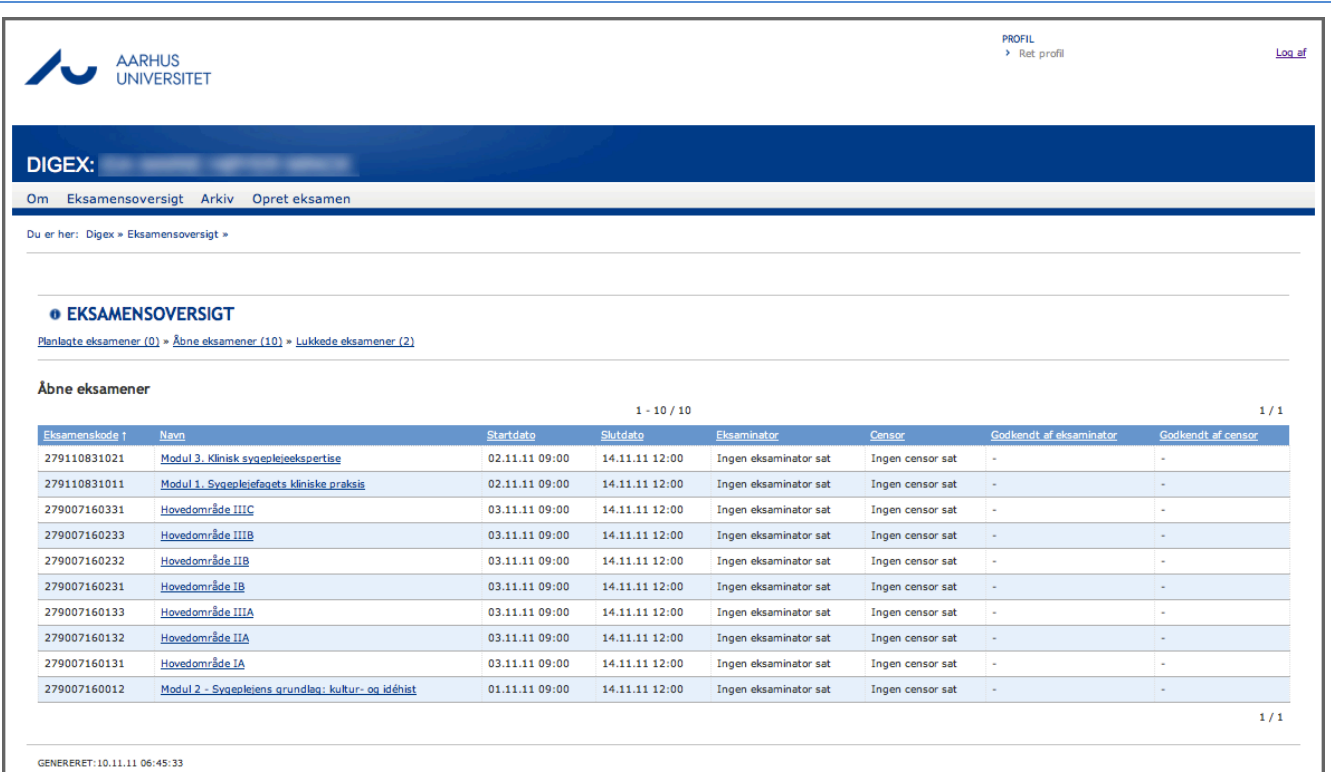

Figur 5. Illustration af studiesekretærs oversigt over igangværende prøver.

\section{Den digitaliserede prøves workflow}

I det store hele adskiller den digitaliserede skriftlige prøves overordnede workflow sig ikke nævneværdigt fra den velkendte manuelle afvikling. Studiesekretæren administrerer en given skriftlig prøve, de studerende får udleveret opgaver og afleverer besvarelser, og eksaminator/censor bedømmer slutteligt besvarelserne og indleverer karaktererne. Den store forskel ligger i forenklingen, sammenkoblingen og smidiggørelsen af de underliggende arbejdsopgaver og reduceringen af manuelle behov.

I DigEx kan studiesekretæren på baggrund af en given eksamenskode oprette en prøve, hvor oplysninger om studerende, ECTS-point, studieordning mv. automatisk bliver trukket fra det studieadministrative system (STADS). Prøven kan dernæst sættes op med de nødvendige informationer; tidspunkt for udlevering af opgaveformulering (hvis det er 
en bunden prøve), selve opgaveformuleringen, tidspunkt for afleveringsfrist, eventuelle dispensationer til studerende med senere afleveringsfrist mv. Opgaveformuleringen bliver således automatisk gjort tilgængelig for de studerende ved det definerede udleveringstidspunkt, hvorefter de studerende kan uploade besvarelser samt eventuelt ekstramateriale indtil afleveringsfristen. Studiesekretæren kan endvidere fremsøge bedømmere og tildele dem til prøven eller de enkelte studerende, således af deres besvarelser umiddelbart efter afleveringsfristen gøres direkte tilgængelige for de valgte bedømmerne i en given censureringsperiode.

Studiesekretæren har således mulighed for at opsætte en prøve i DigEx med alle relevante informationer (jf. illustration af animeret workflow), når han/hun har tid forud for selve afviklingen af den pågældende prøve. Både udlevering af opgave, modtagelse af besvarelser samt videredistribution af besvarelser (herunder også særlig information og bilag) til bedømmerne kan derved forberedes og gøres tilgængelig automatisk. Traditionelt er arbejdsbyrden for studiesekretæren høj og koncentreret under den korte eksamensperiode. Det kalder på studiesekretærens koordination og systematisering $\mathrm{i}$ håndteringen og distributionen af opgaver og besvarelser. Med DigEx og den digitaliserede afviklingsform minimeres behovet for manuelt overarbejde inden for en kort presset tidsperiode og flyttes i stedet frem, så opsætning af prøven kan foregå på et hvilket som helst tidspunkt inden prøvens tidsramme, hvorved det smidigt kan tilpasses ind i de øvrige arbejdsopgaver.

De studerende får ligeledes minimeret de fysisk bundne arbejdsopgaver i forbindelse med en skriftlig prøve, hvilket frigør tid til udarbejdelse af selve besvarelsen. Afhentning af opgaveformulering, udskrivning, kopiering og aflevering af besvarelsen er erstattet af direkte online adgang fra den computer, de i forvejen skriver besvarelsen på. Undervejs i prøveperioden kan DigEx anvendes til backup af besvarelsen, og den officielle forside, som normalt udskrives og indsættes som omslag til besvarelsen, udfyldes i stedet online i forbindelse med upload. Besvarelsen afleveres som PDF, hvilket sikrer at formatering og tekst forbliver ensartet og fastlåst, så eventuelle tvister om tekst-sletning og -ændring efter aflevering undgås. Eventuelle digitale bilag, der ikke kan figurere i selve besvarelsen, kan uploades som ekstramateriale. Bilag kan være alt andet end PDF, eksempelvis film-/lydklip, programstumper eller regneark. Som en ekstra tryghed kan man som studerende slutteligt få tilsendt en kvittering per mail, der dokumenterer ens rettidigt afleverede besvarelse samt bilag.

Umiddelbart efter de studerendes afleveringsfrist bliver besvarelserne gjort tilgængelige på DigEx for de relevante bedømmere; al fordeling og distribution sker automatisk på baggrund af studiesekretærens opsætning af den givne prøve ${ }^{5}$. Bedømmerne har således online adgang til

5 Fordelingen af besvarelser til bedømmere kan også ske efter afleveringsfristen. I samme øjeblik en bedømmer tildeles en besvarelse af studiesekretæren vil den blive tilgængelig for bedømmeren i DigEx. Ved sygdom eller andre uforudsete hændelser er det således enkelt og hurtigt at omfordele besvarelserne til en anden bedømmer. 
besvarelserne i en given censureringsperiode, hvor de kan læse, kommentere og bedømme de studerendes arbejde. Besvarelserne kan downloades til læsning og kommentering på bedømmerens computer, eller for så vidt til udskrivning, hvis den traditionelle papirform ikke kan undværes. Det særlige ved platformen DigEx er dog, at der i tilknytning til bedømmelsen er blevet udviklet et online PDF-værktøj, kaldet DigEx Reader, der gør det muligt at læse, kommentere og annotere i besvarelserne direkte i browseren. Dette har en række umiddelbare fordele, samt på sigt nogle perspektiver, der vil kunne smidiggøre bedømmelsesprocessen i endnu højere grad.

\section{DigEx Reader - online kommentering}

Ved at holde læsning og kommentering af besvarelserne online slipper man først og fremmest for at skulle administrere og versionere filer lokalt på sin computer, ligesom løsningen ikke bliver afhængig af brugernes computer og installeret software og rettigheder i tilknytning hertil. I stedet kan man med et enkelt klik i DigEx åbne en besvarelse og herefter starte læsningen og eventuelt. kommenteringen. Alle annotationer gemmes direkte og simultant på serveren, hvorved man er sikret, at ens arbejde hele tiden er gemt og sikret mod eventuelle program- eller computernedbrud. Standardannotationer som overstregning af tekst, kommentarer til tekst og forskellige symboler (flueben, minus, plus mv.), der kan placeres på siderne, fungerer på samme måde som i gængse PDF-programmer, såsom fx Adobe Reader X' ${ }^{6}$. Derudover er der på baggrund af feedback fra testdeltagere blevet udviklet et "generelt" noteværktøj, hvor man kan skrive kommentarer og noter til besvarelsen som helhed, og som derved nødvendigvis ikke knytter sig til et enkelt sted i teksten. Endvidere vil annotationerne (de tekstspecifikke og de generelle) efterfølgende kunne gøres tilgængelige for den enkelte studerende, hvis bedømmeren vælger det - eller ligeledes kunne gøres tilgængelige for anden bedømmer. Herved vil en bedømmers annotationer kunne anvendes i en efterfølgende vejledningssituation - hvad enten den er individuel eller kollektiv med de studerende. Når en besvarelse er bedømt kan man tilknytte en karakter til den studerende, således alle relevante informationer er samlet ét og samme sted, forud for en evt. censur og votering.

6 Standardannotationerne i DigEx Reader overholder PDF-standarden, hvorved de er kompatible med eksempelvis Adobe Reader X. Derved kan man downloade en kommenteret besvarelse og fortsætte læsning og kommentering offline. 


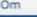

Du er her: Digen.

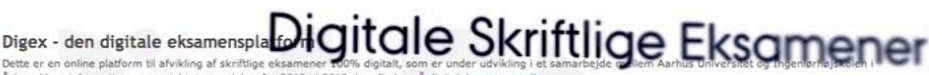

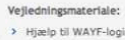
DEMOVIDEO

Figur 6. Demonstrationsvideo af DigEx og de tre brugerroller med dertil knyttede funktioner

Der er altså allerede i det eksisterende scenarium en række fordele i den integrerede DigEx Reader, men det er særligt på længere sigt, at det fulde potentiale vil kunne udfoldes mere. Bedømmelsen af besvarelserne bliver med DigEx Reader ikke bundet til én digital enhed, men er tilgængelige fra alle enheder med netadgang, hvilket øger fleksibiliteten af bedømmelsesprocessen markant. Af samme grund gøres der i Projekt Digital Eksamen forsøg med håndholdte tablets, så som iPads, Asus Transormer og Lenovo Thinkpad. Ideen er, at man således kan læse og kommentere besvarelserne med samme online applikation (DigEx Reader) uafhængigt af om man bruger mac, PC, iPad eller lignende. Man vil eksempelvis kunne starte på en besvarelse på ens stationære kontor-pc, gøre den færdig på sin iPad på vej hjem i bussen, starte på en ny besvarelse på sit hjemme-pc og afslutte den i sofaen med sin bærbare i skødet uden på noget tidspunkt at skulle flytte rundt på filer eller veksle mellem forskellige læseapplikationer. Man skal blot logge ind og fortsætte hvor man slap.

Ud over den tekniske og platformmæssige fleksibilitet fastlåses man heller ikke til én arbejdsstation, hvilket åbner for et rigere udvalg af arbejdsstillinger og brugssituationer, der kan gøre den ganske tidskrævende bedømmelsesproces mere eller ligeså komfortabel som tidligere. Det ofte fremførte argument om, at kun papiret understøtter fleksibiliteten i at rette besvarelser i sommerhuset, i hængekøjen osv., gøres hermed til skamme.

\section{Projektets faser}

Projekt Digital Eksamen løber fra forår 2010 til efteråret 2012. Indeholdt i projektperioden, hvor den digitale løsning (DigEx og DigEx Reader) 
udvikles, afvikles der fire pilottest på reelle eksamensafleveringer. Første pilotfase blev afviklet vinteren 2010 med 5 prøver, involverende 200 studerende og 10 bedømmere og 1 studiesekretær. Fokus var her på at etablere et digitalt workflow og sikre sig at det fungerede. Anden pilotfase blev afviklet sommeren 2011, hvor 62 prøver testet, involverende 2.320 studerende, 185 bedømmere og 18 studiesekretærer. Her var fokus på udvidet funktionalitet for både studerende (fx inkorporation af eksamensforsider), studiesekretærer ( $\mathrm{fx}$ let tildeling af bedømmere, info til censorer, let administration af igangværende eksamen mv.) og bedømmere (etablering af DigEx Reader til online kommentering, karakterangivelse mv.).

Projektet er halvvejs i projektet og der resterer derfor to endelige pilottest. Pilottest 3, som skal afvikles vinter 2011, vil have fokus på integration med nyt studieadministrativt system (STADS), som fodrer relevante data til DigEx (eksamenskode, alle eksamenstilmeldte, udpegede bedømmere osv.), samt på yderligere løft og udvidelse af funktioner for brugerne. Det er planen at pilottest 3 afprøver 100 eksaminer, involverende 3-4.000 studerende, 3-400 bedømmere og 20-30 studiesekretærer. Afslutningsvis vil der i sommeren 2012 blive afholdt den endelige pilottest 4 med 250 prøver, involverende 8-10.000 studerende, 8-900 bedømmere og +30 studiesekretærer. Fokus vil her være på inkorporering af videokonference til brug for online censur, direkte karakterinddatering i det studieadministrative system STADS, samt udvidet kommenteringsfunktionalitet i DigEx Reader (fx indtaling af kommentarer mv.).

\section{Foreløbige evalueringer}

Alle projektets faser bliver evalueret, og særligt ved de konkrete pilottests udføres der både kvalitativ og kvantitative evalueringer og opsamlinger. Til de enkelte pilottests er der således udarbejdet et evalueringsskema, indeholdende ca. 30 spørgsmål om det eksamensforløb, de hver især har deltaget $i$, hvad enten der er tale om en studerende, en studiesekretær eller en bedømmer. Ud over de konkrete spørgsmål, gives der mulighed for frie kommentarer, påpegning af ønskede forbedringer og henvisning til konkrete uhensigtsmæssigheder. De konkrete evalueringsskemaer følges op af interview og snak med udvalgte brugere, ligesom der udvælges personer til videooptagne testimonials.

For begge evalueringer (pilottest 1 og 2), er det generelle billede meget positivt, særligt når det gælder de studerende og studiesekretærerne, mens bedømmerne har en lidt større andel af skeptikere, om end de også overvejende er positive. Det bør anføres, at de involverede bedømmere, studerende og studiesekretærer i pilottestene er en blanding af frivillige, interesserede og "tvungne"7 i relation til deltagelsen. Studerende har generelt ikke fået lov at vælge, men er blevet "tvunget" til deltagelse eller de har ikke modsat sig. For størstedelen af studiesekretærernes

7 I denne sammenhæng skal "tvungen" anskues mildt, som en kraftig opfordring på baggrund af leders ønske, eller som led i institutionens ønske om at deltage i forsøget. 
vedkommende har de selv ønsket at deltage. Kun enkelte er blevet "tvunget" af deres overordnede, hvilket også er det generelle billede for bedømmerne. Nedenstående evalueringer skal således rettelig ses i det lys, at de adspurgte således ikke er tilfældige, men udvalgte, med en overvægt af frivillige. Endvidere refereres der kun til seneste pilottest 2 .

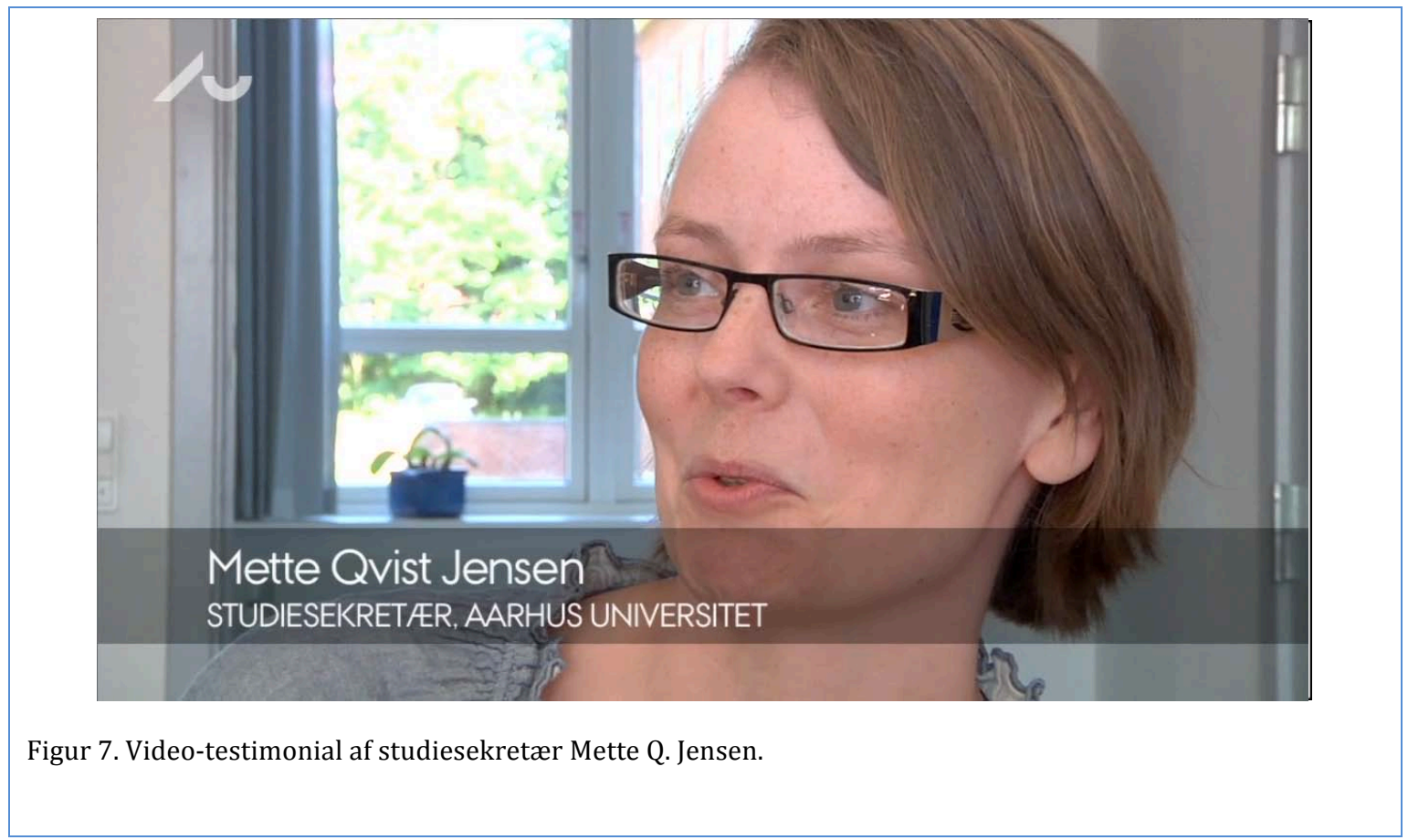

\section{Evaluering af pilottest 2: Studiesekretaer}

I evalueringen af pilottest 2 deltog 11 ud af 18 medvirkende studiesekretærer, hvorved svarprocenten blev 61\%. Størstedelen af de medvirkende studiesekretærer udtrykte begejstring for den digitale afvikling af skriftlige prøver. På spørgsmålet: "Vil du foretrække fremover at skulle afvikle og håndtere jeres skriftlige eksamener gennem DigEx?" svarer hele 83,3 procent "meget gerne" eller "gerne", mens de resterende 16,7 procent svarede "måske". Ingen af studiesekretærerne var dermed decideret imod at fortsætte med eksamensafvikling i digital form.

Ikke overraskende vurderer studiesekretærerne langt overvejende at gennemførelsen af pilottesten som værende succesfuld. Således svarede 75 procent af studiesekretærerne "meget succesrig" og "overvejende succesrig" på spørgsmålet om vurderingen af deres deltagelse. Årsagerne hertil skal, ifølge studiesekretærerne selv, blandt andet findes i den store arbejdsfleksibilitet og det store proces-overblik, DigEx gav dem i deres eksamensarbejde - helt fra oprettelsen af eksamenen til aflevering, bedømmelse og afsluttende arkivering. Studiesekretærerne udtrykker stor tilfredshed med at slippe for den fysiske håndtering af eksamensopgaverne og -besvarelserne (udlevering, modtagelse, forsendelse og arkivering), hvilket giver dem færre stress-perioder og mere fleksibilitet og overskud til kvalitet $\mathrm{i}$ arbejdet. 
En minoritet på 9 procent fandt dog den digitaliserede eksamenshåndtering gennem DigEx "lidt mere besværlig" end normalt. Deres kritik gik hovedsageligt på det eksisterende besvær i de manuelle processer, der stadig skulle udføres i pilottest 2, eftersom DigEx endnu ikke var fuldt integreret med det studieadministrative system. Efterfølgende er DigEx blevet fuldt integreret med det nye STADS, og der vil fremover ikke være overlap af processer systemerne imellem. Studiesekretærerne pegede desuden på behovet for at kunne sammenflette eksamenskoder og oprette eksamener på tværs af fakulteter og hovedområder. En tendens som er stigende, eftersom uddannelserne bliver mere fleksible og der arbejdes på at åbne det indre uddannelsesmarked på AU. Dette er ligeledes en funktionalitet som efterfølgende er blevet implementeret i DigEx.

Endelig er det værd at bemærke, at studiesekretærerne også tillægger supportfunktionen og brugervenligheden af DigEx stor betydning for deres succes. Konkret fremhæves projektets hotline og sidemands-instruktioner som afgørende for at skabe tryghed i pilottesten, og for det at komme hurtigt og smidigt ind i brugen af DigEx. Nedenfor vises et udsnit af resultater fra seneste pilottest-evaluering i lagkageformat:

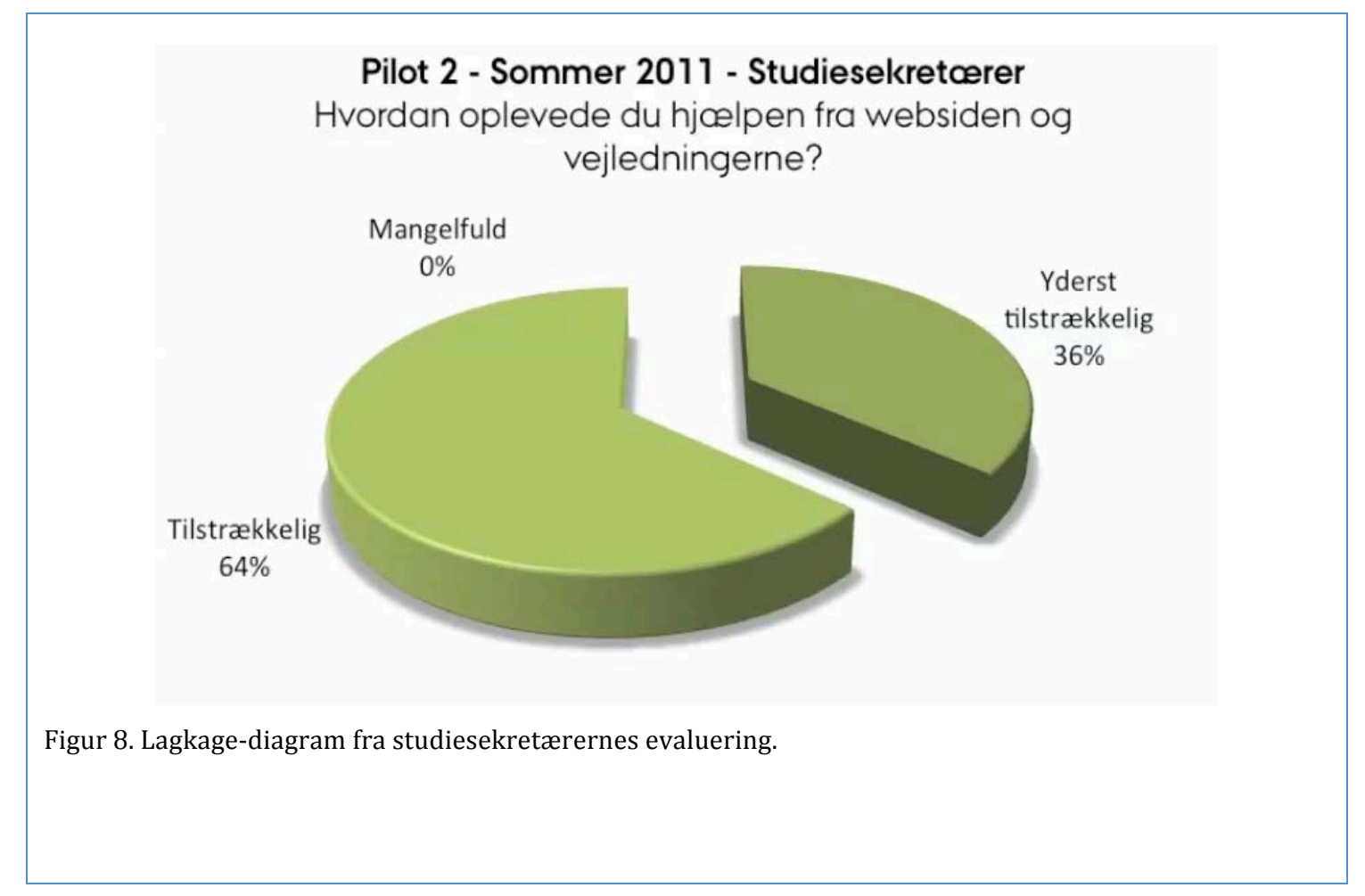




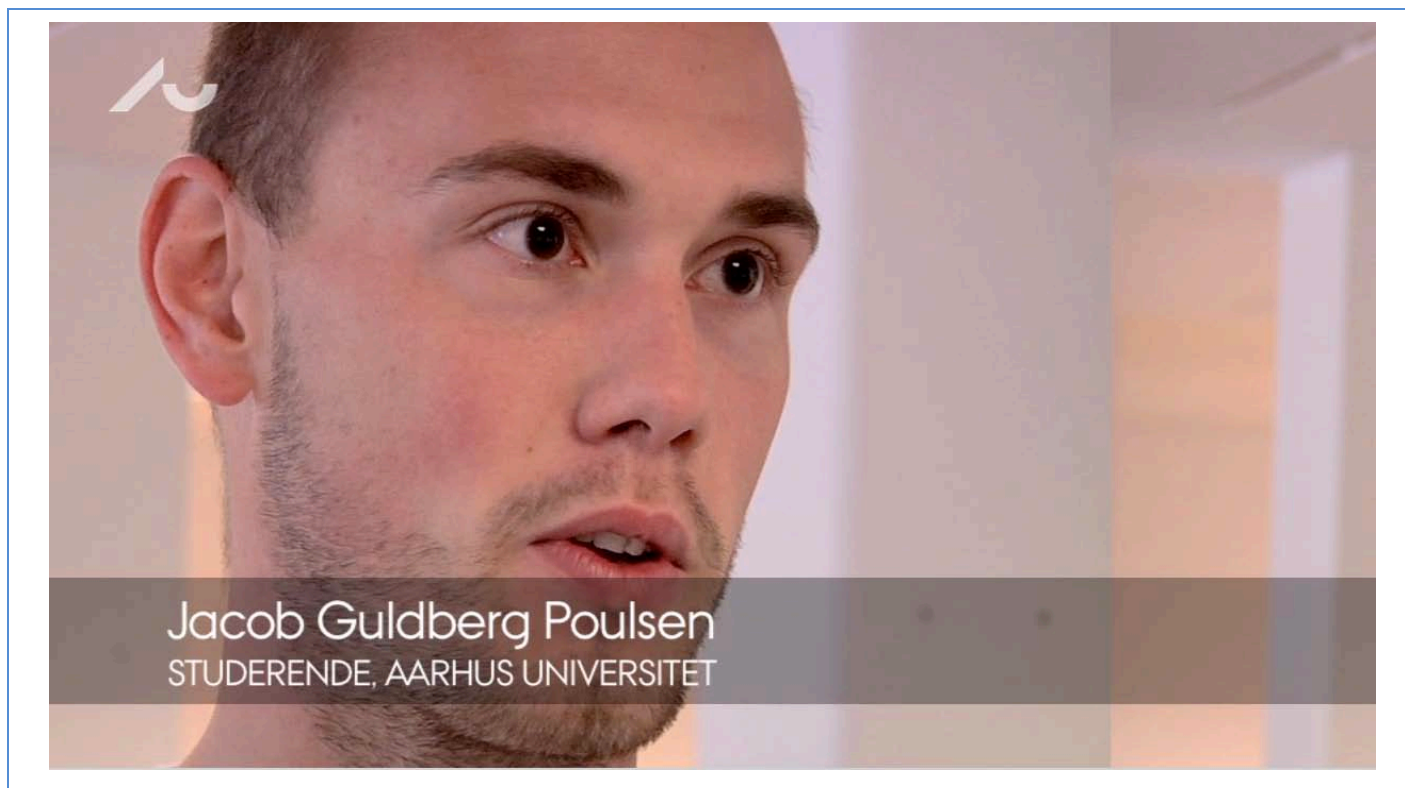

Figur 9. Video-testimonial fra studerende Jacob G. Poulsen.

\section{Evaluering af pilottest 2: Studerende}

I evalueringen af pilottest 2 deltog 679 ud af 2320 medvirkende studiesekretærer, hvorved svarprocenten blev 29\%. Langt størstedelen af de studerende, der deltog i den digitale eksamensafvikling, var meget eller i overvejende grad positive over den digitaliserede eksamensform. På spørgsmålet: "Hvordan vurderer du som helhed gennemførelsen og din deltagelse i dette pilotprojekt?" svarede hele 92 procent af dem, at de betragtede gennemførelsen som succesfuldt eller meget succesfuldt. Blot i underkanten af 4 procent af de studerende var decideret imod digital aflevering på DigEx-platformen. Hele 96 procent af de studerende mente desuden, at DigEx enten var meget, eller rimeligt brugervenligt.

Evalueringen af den første pilottest viser, at de studerendes største anke var, at den obligatoriske forside til besvarelsen ikke var nem at hæfte på den pdf-fil, som de skulle aflevere som besvarelse. Denne feedback afstedkom, at den officielle forside i stedet blev integreret i DigEx, så de studerende blot fremover udfylder forsideinformationerne, når de uploader deres besvarelse, således disse oplysninger automatisk vedhæftes besvarelsen. Evalueringen af pilottest 2 viser, at mere end $75 \%$ af de studerende synes at denne måde at udfylde forsideoplysninger på er $\emptyset$ nskelig og fordelagtig

Ikke overraskende fremhævede mange studerende stor begejstring ved fleksibiliteten af at kunne uploade sin eksamensbesvarelse frem for, som tidligere, først at skulle printe og indbinde besvarelsen, samt evt. brænde bilag og ekstra materiale på CD-rom, førend de fysisk skulle møde op og aflevere den. At kunne klare det hele hjemmefra, blev oplevet som naturligt, fleksibelt og meget positivt, særligt for de mange studerende som tilbragte opgaveskrivningen væk fra universitetet (hos forældre, i sommerhus og lignende). En del studerende følte sig desuden mere sikre 
og trygge ved løsningen, idet de kunne få tilsendt officiel kvittering ved afleveringen - noget som ikke ellers udstedes, når der afleveres på studiesekretærens kontor.

De studerende fremhævede ikke nogen decideret kritik af DigEx og digitliseringen af deres eksamen, men oplevede dog i mindre omfang lidt slør i informationerne om pilotforsøget og om hvem der var ansvarlig og hvem der supporterede dem. Disse indvendinger er senere blevet omdannet til mere klare procedurer for ansvars og rollefordeling mht. kommunikation, information og support. Afslutningsvis er det ellers værd at bemærke, at den mest gængse frie kommentar i evalueringen fra de studerende omhandler spørgsmålet om hvorfor DigEx ikke var blevet iværksat mange år tidligere, eller at det var på tide med en sådan "naturlig" løsning. Nedenfor vises et udsnit af resultater fra evalueringen af pilottest 2 i lagkageformat:

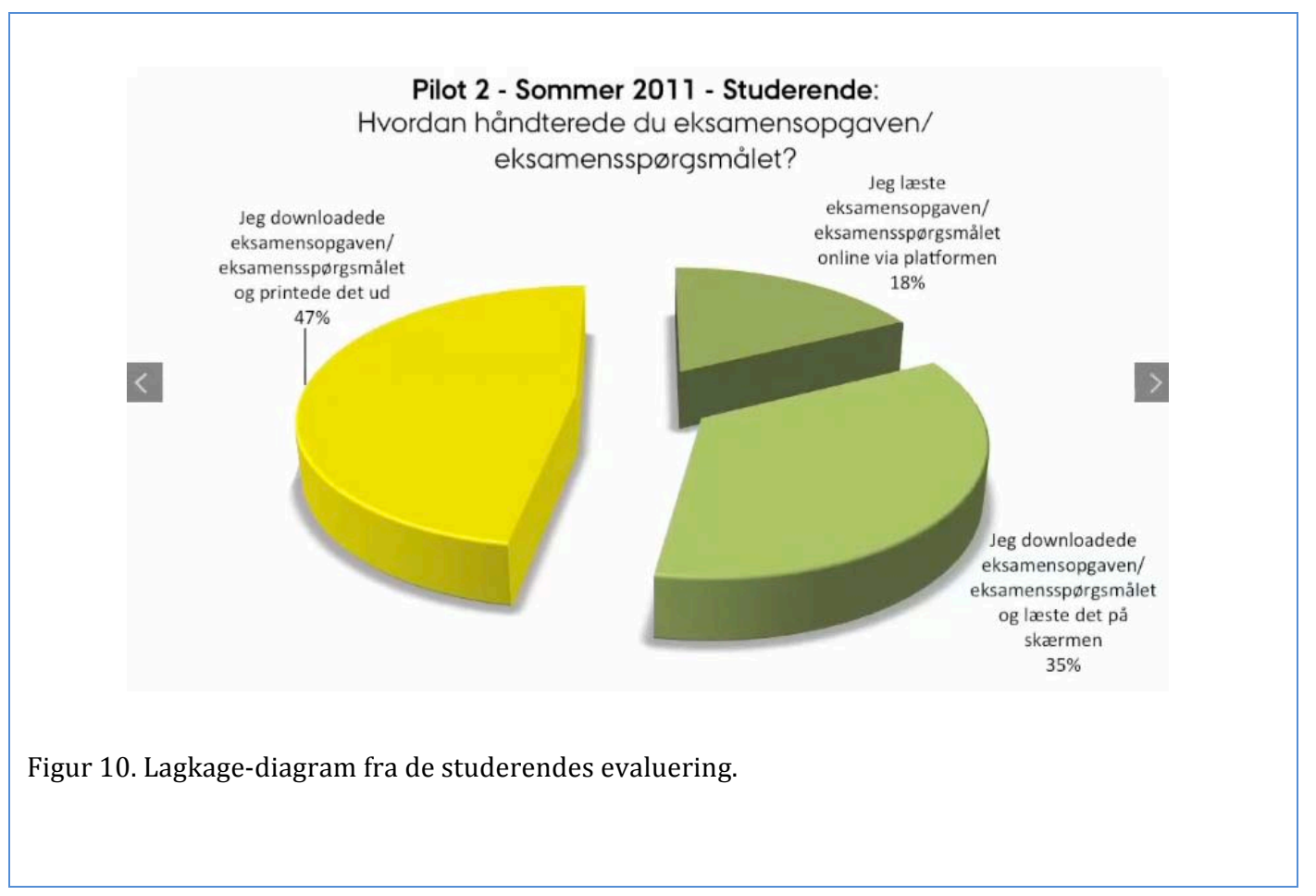




\section{Evaluering af pilottest 2: Bedømmer}

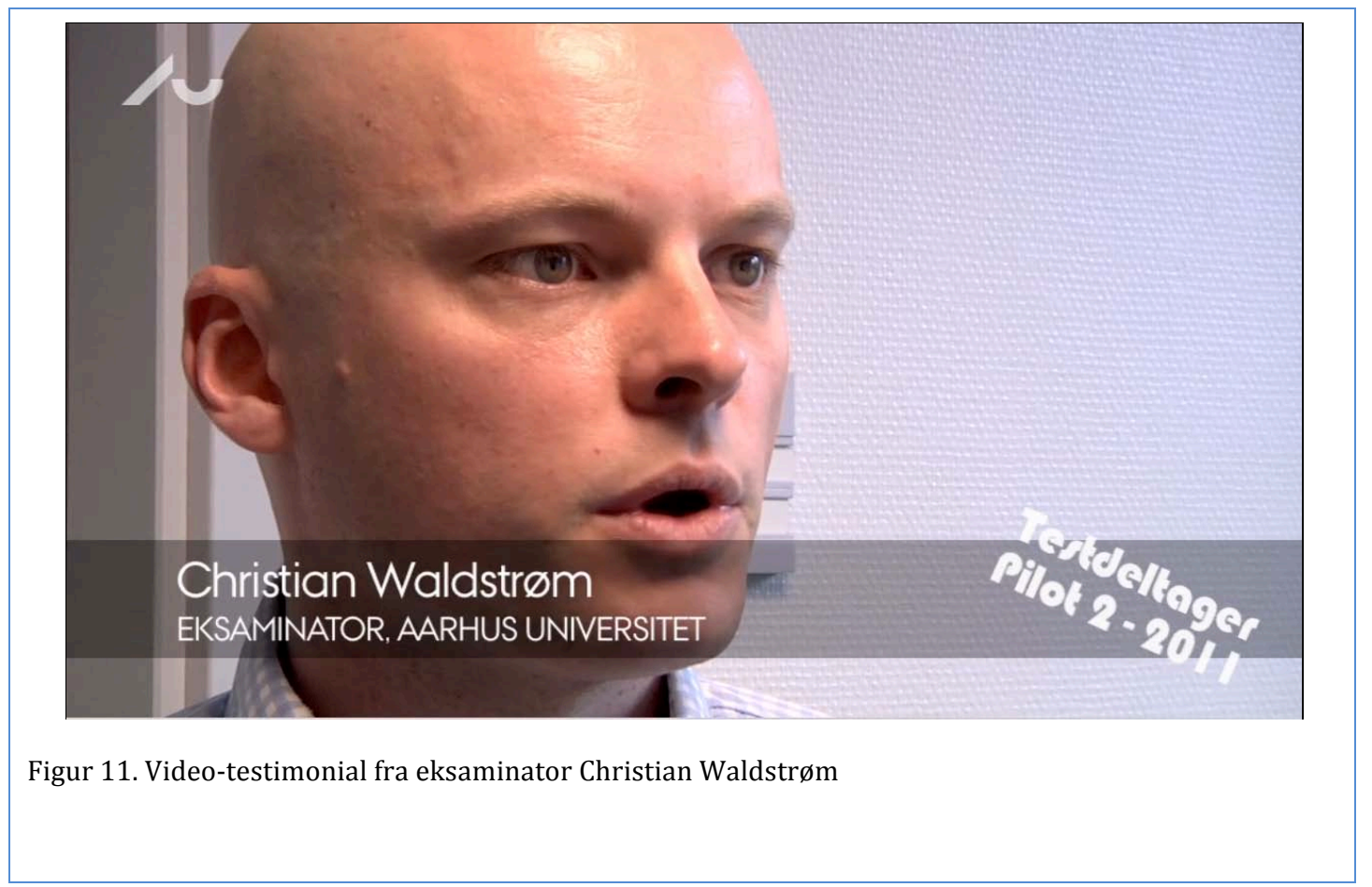

I evalueringen af pilottest 2 deltog 107 ud af 185 medvirkende bedømmere, hvorved svarprocenten blev 58\%. De medvirkende bedømmere viste samlet set en lille overvejende positiv tendens, når det kommer til både den specifikke digitale bedømmelsesproces såvel som den digitaliserede eksamensafvikling som helhed. På spørgsmålet: "Vil du foretrække fremover at skulle foretage bedømmelsen af de studerendes eksamensbesvarelser digitalt?" svarede $67 \%$ af de medvirkende, at de gerne vil, eller måske gerne vil, fortsætte med en digital bedømmelse, ligesom kun $21 \%$ var decideret imod at modtage og tilgå de studerendes eksamensbesvarelser digitalt. Adspurgt til vurderingen af pilotprojektet som helhed, var $47 \%$ positive stemte, $20 \%$ negative stemte, mens $33 \%$ hverken var positive eller negative stemte

En af grundene til at en stor del af de medvirkende bedømmere ser positivt på en digitalisering af de skriftlige eksaminer, skal i følge flere af dem selv, findes i de mange ekstra muligheder, en digital løsning åbner op for. Især muligheden for at få samlet og arkiveret de studerendes eksamensbesvarelser ét sted, frem for at skulle slæbe dem frem og tilbage i fysisk form mellem fx arbejdsplads og hjem (evt. sommerhus/refugium), fremhæves som værende særligt positivt. Mobilitet spiller ligeledes en afgørende rolle for bedømmernes syn på digitaliserings-forsøget. Brugere 
af iPads tenderer en mere positiv holdning til den digitale bedømmelse frem for brugere af stationære og bærbare PC'er, og en stor del af bedømmerne fremhæver vigtigheden af nemt at kunne medbringe besvarelserne overalt, og at kunne tilgå dem hvorfra de lyster.

Også platformens integrerede pdf-værktøj, DigEx Reader, hvor man direkte i browseren kan læse og kommentere de studerende besvarelser er blevet positivt modtaget. Dette skal tilmed ses i lyset af, at DigEx Reader i Pilot 2 var helt nyudviklet og således endnu ikke havde så mange veludviklede funktioner. Ligeledes er DigEx som helhed overvejende blevet opfattet som værende brugervenlig og har tilvejebragt de nødvendige oplysninger på en enkelt og let tilgængelig måde. 59 procent af bedømmerne fandt, at det var "let" eller "meget let" at få adgang til de studerendes besvarelses, mens kun 27 procent syntes det var "lidt" eller "mere besværligt".

Modsat de studerende og studiesekretærerne fremgår det også af evalueringen, at blandt bedømmerne findes der en ikke uvæsentlig mængde (henholdsvis 20\% og 35\%), som ikke finder digitaliseringen af de skriftlige eksaminer en god idé, eller som oplevede pilotforsøget som besværligt og tidsforøgende. Noget af kritikken kan henføres til problemer med login for censorerne (som var uvante med AUs login, eller havde glemt brugernavn eller password), og til manglende funktionaliteter i hovedsagligt i håndteringen og kommenteringen af de enkelte besvarelser. En række af disse forhold bliver samlet op i udviklingen af DigEx fremover.

Imidlertid er det også værd at gøre sig klart, at den rejste kritik ikke er uvæsentlig om end den repræsenterer et mindretal, og at den ikke nødvendigvis er eller kan løses teknologisk. For bedømmerne gælder, at langt størstedelen af deres arbejde er læsning, og at deres arbejde langt overvejende udgår store dele af det samlede arbejde, der udføres på en skriftlig prøve. Modstanden eller kritikken er således ikke uden vægt, ligesom de forslåede forandringer som følge af digitaliseringen ikke er uvæsentlige. Evalueringen peger således på, at der er tale om et stort brud på vaner for bedømmerne, som kalder på en større indsats kommunikations og kompetencemæssigt.

Når det så er sagt, peger evalueringen også på, at bedømmerne selv forventer at håndteringen og bedømmelsen af de skriftlige prøver vil blive digitaliseret med tiden. Hele $86 \%$ svarer således, at de forventer en digitalisering indenfor få år. Nedenfor vises et udsnit af resultater fra seneste pilottest-evaluering i lagkageformat: 
Pilot 2 - Sommer 2011 - Eksaminator/censor Hvordan oplevede du adgangen til de eksamensbesvarelser, du skulle bedømme?

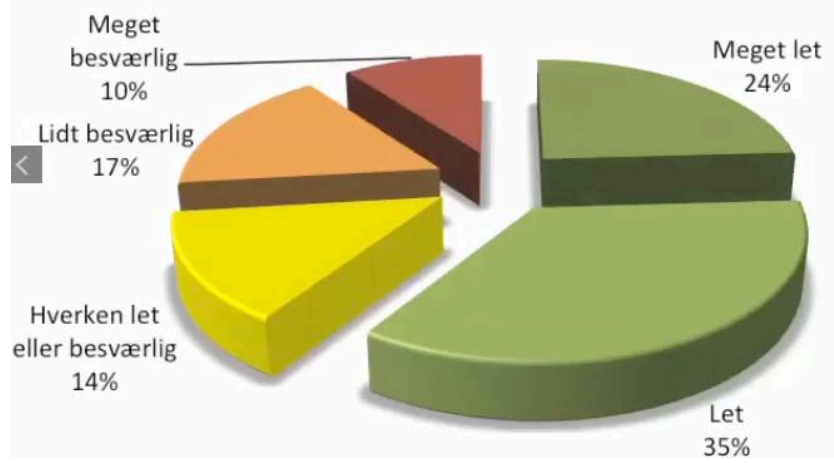

Figur 12. Lagkage-diagram fra eksaminatorer/censorers evaluering.

\section{Potentialer og udfordringer}

Det er klart, som evalueringen blandt bedømmerne viser, at digitaliseringen af en kerneaktivitet som de skriftlige eksaminer udgør for universitetet, ikke er problemfri eller en enkel opgave. En digitalisering, og dermed ændring af håndteringen af de skriftlige eksaminer og prøver, betyder også en ændring af arbejdsgange og faste rutiner for mange mennesker. På Aarhus Universitet vil 40.000 studerende og 10.000 ansatte blive berørte. En sådan proces skal derfor ske med omtanke og kan ikke foregå "over night".

Omvendt er det værd at holde sig formålet for øje. Digitaliseringen sker med afsæt både i kvantitative og kvalitative målsætninger. Dvs. ønsket om på den ene side at reducere ressourcer i form af overflødige og belastende arbejdsgange, papir og transport, og på den anden side at øge kvaliteten i afviklingen af den skriftlige eksamen for både studerende, bedømmere og studieadministrativt personale. Teknologien bag digitaliseringen skal altså benyttes både til at gøre det nemmere og billigere for universitetet, men omvendt også gøre det nemmere og bedre for dets brugere. Det kan lyde voldsomt, men korresponderer faktisk med de grundlæggende principper for teknologi, som Adam Smith grundlagde for snart 250 år siden med sin beskrivelse i "The Pin Factory" fra 1776. Ifølge Adam Smith kan teknologien hjælpe med at forbedre produktionen, kvaliteten, mængden og effekten gennem arbejdsdeling, specialisering og skalering, således at udbyttet kunne blive billigere, bedre og mere præcist. Principper som stod bag den senere industrialisering af den vestlige verden.

Men der er langt fra teorier og teknologiske principper til den skinbarlige virkelighed. Der er god grund til at tro, at Projekt Digital Eksamen kan indfri både de kvalitative og kvantitative målsætninger med DigExløsningen. På baggrund af nulpunkts- og midtvejsmåling i projektet af de kvantitative effekter (transport, mængde af arbejde, omkostninger til papir, konvolutter mv.) er det rimelig sikkert, at de kvantitative målsætninger 
nås. Samtidigt peger ovenstående evalueringer klart på, at de kvalitative målsætninger (nemmere adgang, større overblik, flere værktøjer og større sikkerhed mv.) også kan indfris af løsningen.

Men i kølvandet på digitaliseringen af de skriftlige prøver følger også forandringer, som er værd at hæfte sig ved. Forandringer som skaber grobund for nye potentialer, men også forandringer, som i konteksten til de skriftlige prøver ændrer vilkår for en masse mennesker. Samtidigt bevæger vi os ud i nyt farvand, hvor vi ikke er rutinerede søfarer, og som rummer behov for ny forståelse, nye regler og nye vaner.

\section{Nye sociale kontekster og arbejdsgange}

Et godt eksempel på at forandringer har flere sider, er de studerendes aflevering af besvarelser. På den en side taler tallene deres tydelige sprog om at de foretrækker den digitale aflevering, både på grund af de åbenlyse fordele for dem direkte og for elementet af naturlighed i deres kultur. Samtidigt påpeger de studerende, at der dermed sker et tab eller en forandring af deres sociale forhold. For det var hos studiesekretæren kl. 12.00 den givne afleveringsdag, at de mødte hinanden og besluttede, hvor de skulle fejre afleveringen og den netop startede ferie. Dette sociale og "naturlige" element er nu blevet fjernet som led i forbedringen og rationaliseringen af andre. De studerende bliver således overladt til at finde nye mønstre og metoder til at koordinere dette specifikke sociale og "naturlige" behov, som man må erkende også er en vigtig del af et studieliv. I Projekt Digital Eksamen forsøgte vi os med at tilbyde en online Facebookgruppe i forlængelse af de studerendes aflevering, hvor det sociale kunne skabes og aftaler koordineres. Men ved evalueringen frabad de studerende sig denne "officielle" sammenblanding af den formelle prøve og deres privatsfære.

Og i lighed hermed, kan man også anskue forandringen for bedømmerne. En række af dem vil ikke se digitaliseringen og afskaffelsen af papiret som en direkte fordel for dem, men mere som en konsekvens, der rammer dem. At modtage besvarelserne til bedømmelse digital rummer for nogle en helt ny måde at bedømme på og en række nye rutiner, som skal indlæres. At læse på skærm og kommentere på skærm, rummer nye måder at navigere, skrive og ultimativt lave bedømmelses-arbejde på. Det vil komme naturligt for nogle, men rumme flere udfordringer for andre. Ligesom så mange andre processer, vil en digitalisering af de skriftlige prøver også være en klassisk forandringsproces, som vil tage tid og rummer de klassiske udfordringer som forandring af vaner og rutiner medfører.

\section{Eksempler på nye understøttende muligheder for bedømmere}

Hertil er det væsentligt at få understøttet bedømmelse med så mange og så gode digitale redskaber som muligt, men også pege på de nye muligheder som opstår i kølvandet på digitaliseringen, og som var umulige før. Et godt eksempel er plagieringskontrol. En sådan vil nu kunne automatiseres og gennemføres systematisk. En opgave som ikke var mulig ved papirafleveringen og som rummede betydelige udfordringer for bedømmerne, idet de var pålagt bevisbyrden. Med en automatisk screening for plagiat bliver bedømmernes arbejde hermed lettet og løftet kvalitetsmæssigt. 
Et andet eksempel kunne være selve censur-delen og voteringen bedømmerne imellem. Den foregår ofte via telefon eller fysisk møde (der kan involvere rejse), som rummer besværligheder i kraft af de store mængder papir som skal håndteres, flyttes og konfereres om ved fysisk møde, eller som man har svært ved at orientere sig sammen om via telefon. Her kunne inkorporation af videokonference være en fordel, da bedømmerne hermed let vil kunne mødes online, se hinanden og $\mathrm{i}$ fællesskab kigge på og gennemgå besvarelserne, idet de begge vil kunne se en og samme besvarelse samtidigt. Desuden vil de ikke behøve orientere sig i telefonnumre mv. Men blot fange vedkommende når han/hun var online.

Endelig kunne man også fremhæve indtaling af mundtlige kommentarer som et godt eksempel på afledte effekter og muligheder af digitaliseringen. Når bedømmelsen foregår digitalt via computer, rummer det også mulighed for at kompensere for de skriftlige kommentarer. Man ville let kunne indtale kommentarer i stedet til gavn for fx sprogfag eller for undervisere, som ikke behersker det skriftlige element så godt - fx som konsekvens af den stigende internationalisering.

\section{Fremtidens digitale prøve-landskab}

Ovennævnte eksempler viser tydeligt, at når forandringer skabes, opstår der både muligheder og udfordringer som konsekvens af det. Og dermed også at vanebrud og nye arbejdsgange kan medføre gener og tilvænning for de involverede, som godt nok kan substitueres af digitaliseringen, men måske først løftes af de nye muligheder, som kommer som konsekvens af den. De tre seneste eksempler har også det til fælles, at de netop som konsekvens heraf vil blive implementeret i DigEx-løsningen (sammen med mange andre lignende) frem mod ende projekt- og udviklingsstop i efteråret 2012.

På samme vis kan der opstå udfordringer som konsekvens af digitaliseringen, som kan hindre eller besværliggøre løsningen. Spørgsmål omkring lovgrundlag, sikkerhed og tilgængelighed bliver væsentligt at få afklaret endeligt. Umiddelbart synes nuværende lovgivning at fordre en digitalisering på området, men der kan være uklarhed om det gælder alle aspekter af en fuld digitalisering af området - og er den også tidssvarende til morgendagens brug? Samtidigt bliver det nu væsentligt og rettelig en betingelse, at DigEx-løsningen er sikker, overholder datalovgivning og gængse digitale standarder, ligesom Aarhus Universitet nu forpligter sig på at levere fuld digital infrastruktur døgnet rundt til løsningen. Det går jo ikke at netværk og adgang er "nede", når en prøve skal udleveres eller afleveres, eller at systemet bliver for overbelastet, når alle 40.000 studerende på AU afhænger af dets virken.

En række af disse aspekter arbejdes der selvfølgelig løbende med i Projekt Digital Eksamen og DigEx-løsningen, men påpeges her for at illustrere, at en digitalisering af de skriftlige prøver har forgrenede konsekvenser, der er vigtige at håndtere. Samtidigt er det også værd at bemærke, at som konsekvens af digitaliseringen af de skriftlige prøver, kan man også forvente sig en forandring i selve prøveformaterne. Prøver behøver således ikke længere at være enten blot skriftlige eller mundtlige, men kan let 
fremover indeholde andre teknologiske elementer, ligesom formative og nye summative former kan vinde frem. Når digitaliseringen er blevet hverdag, hvorfor så opretholde gamle eksamens- og prøveformer, kan man spørge. Vil der således være bedre og mere egnede typer, som måler de studerendes læring og viden bedre - mon ikke?

Projekt Digital Eksamen og DigEx-løsningen er således ikke endemålet, men blot begyndelsen på digitaliseringen af prøverne ved de danske universiteter. Da projektet er støttet af ABT-fonden og allerede har opnået signifikante resultater, foregår der allerede nu en dialog med ministerierne om, hvordan viden og løsning kan komme resten af universitetssektoren til gavn. I skrivende stund eksisterer der blandt flere parter velvilje for en national (og international) udbredelse, men det er endnu for tidligt at konkludere på udfaldet heraf. Men det er selvfølgelig projektets håb, at løsning og knowhow kan spredes og at andre interesserede universiteter og uddannelsesinstitutioner frem for at starte forfra, kan hægte sig på projektets erfaringer og teknologi. Du kan følge og læse mere om Projekt Digital Eksamen og DigEx-løsningen på http://digitaleksamen.au.dk 